\title{
PENGARUH MODEL PEMBELAJARAN KOOPERATIF TIPE TEAM GAMES TOURNAMENT TERHADAP PEMAHAMAN KONSEP PESERTA DIDIK PADA PEMBELAJARAN FISIKA
}

\author{
Agustina $^{1}$, Misdalina ${ }^{2}$ Lefudin $^{3}$ \\ Mahasiswa Program Studi Pendidikan Fisika, FKIP, Universitas PGRI Palembang ${ }^{1}$ \\ Dosen Program Studi Pendidikan Matematika, FKIP, Universitas PGRI Palembang ${ }^{2}$ \\ Dosen Program Studi Pendidikan Fisika, FKIP, Universitas PGRI Palembang PGRI ${ }^{3}$ \\ Email: tina010896@gmail.com
}

Diterima: 3 Februari 2020 Disetujui: 20 Agustus 2020

\begin{abstract}
Abstrak
Rumusan masalah dalam penelitian ini adalah pengaruh model Pembelajaran kooperatif tipe Teams Games Tournament terhadap kemampuan pemahaman konsep peserta didik pada pembelajaran fisika kelas X di SMK PGRI 2 Palembang. Penelitian ini bertujuan untuk mengetahui ada atau tidak ada pengaruh model pembelajaran kooperatif tipeTeam Games Tournament (TGT) terhadap kemampuan pemahaman konsep peserta didik pada pembelajaran fisika kelas X di SMK PGRI 2 Palembang. Metode penelitian yang digunakan adalah metode True Experimental Design, Kategori PosstestOnly Control Design. Dalam Rancangan ini sering digunakan dalam Penelitian Eksperimen dengan teknik pengumpulan data diperoleh menggunakan tes, dan dokumentasi. Nilai rata-rata hasil belajar siswa di kelas eksperimen dapat dikategorikan baik yaitu 78,47 dengan menggunakan model tipe Team Games Tournament (TGT), sedangkan nilai rata-rata hasil belajar kelas kontrol dengan tidak menggunakan model kooperatif tipe Team Games Tournament dapat dikategorikan cukup dengan rata-rata hasil belajar siswa adalah 63,05. Berdasarkan perhitungan, diperoleh $\mathrm{t}_{\text {hitung }}>\mathrm{t}$ tabel $=7,105$ $>1,667$ yaitu $\mathrm{t}_{\text {hitung }}=7,105$ dan $\mathrm{t}_{\text {tabel }}=1,667$ maka terima hipotesis $\left(\mathrm{h}_{\mathrm{a}}\right)$ yang berarti ada pengaruh model pembelajaran kooperatif tipe Team Games Tournament (TGT) terhadap kemampuan pemahaman konsep peserta didik pada pembelajaran fisika kelas X di SMK PGRI 2 Palembang.

Kata Kunci: : Pembelajaran Berbasis Masalah, Hasil belajar Fisika.
\end{abstract}

\begin{abstract}
The formulation of the problem in this study is the effect of the Cooperative Learning model of the types of Team Games Tournament on the ability of students to understand the concept of physics learning in class $X$ in SMK PGRI 2 Palembang. This study aims to determine whether or not there is an influence of the cooperative learning model of type of Team Games Tournament (TGT) on the ability of students to understand the concepts of physics in class X learning at SMK PGRI 2 Palembang. The research method used is the Experimental Design method, the category of Posstest-Only Control Design. in this design often used in research experiments with data collection technigues obtained using tests, and documentation.The average value of student learning outcomes in the experimental class can be
\end{abstract}


Agustina., Misdalina., Lefudin. - Pengaruh Model Pembelajaran ...

categorized as good at 78.47 by using the cooperative games tournament type (TGT) Model, while the average value of the learning outcomes of the control class by not using the model cooperative Team Type Tournament games can be categorized enough with the average student learning outcomes is 63.05. Based on calculations $t$ arithmetic $>t$ table $=7.105>$ 1.667 ie $t$ arithmetic $=7.105$ and $t$ table $=1.667$ then accept the hypothesis (ha) which means "There is an influence of the cooperative learning model Team Games Tournament type (TGT) on the ability of students to understand the concept of learning physics in class X in SMK PGRI 2 Palembang.

Keywords: Problem Based Learning, Physics learning outcomes.

\section{PENDAHULUAN}

Pembelajaran adalah salah satu aspek pendidikan yang berpengaruh bagi peningkatan kualitas individu. Menurut Sufairoh (2016, hal. 119) Pembelajaran adalah proses interaksi antar peserta didik, antara peserta didik dan pendidik, dan antara peserta dan sumber belajar lainnya pada suatu lingkungan belajar yang berlangsung secara edukatif, agar peserta didik dapat membangun sikap, pengetahuan dan keterampilannya untuk mencapai tujuan yang telah ditetapkan. Pembelajaran adalah serangkaian kegiatan yang melibatkan informasi dan lingkungan yag disusun secara terencana untuk memudahkan siswa dalam belajar. (Suprihatiningrum, 2017, hal. 75). Lingkungan yang dimaksud tidak hanya berupa tempat kegiatan pembelajaran tetapi juga metode, media dan peralatan yang diperlukan untuk menyampaikan informasi.

Fisika sebagai salah satu bagian dari Sains berperan penting dalam membentuk siswa yang berkualitas. Fisika merupakan pengetahuan, gagasan dan konsep yang diperoleh dari pengalaman melalui proses ilmiah (Prihatiningtyas, 2013, hal. 19). Fisika berkaitan dengan aspek produk, proses ilmiah, dan sikap. Konsep-konsep serta teori dan hukum fisika merupakan produk yang diperoleh melalui proses ilmiah seperti melakukan pengukuran, percobaan, dan diskusi yang melibatkan peserta didik secara langsung dalam kegiatan tersebut (Sari, 2016, hal. 176). Gunawan et al. (2016) menyatakan bahwa beberapa konsep fisika yang abstrak seringkali menjadi kendala bagi guru dalam menyampaikan materi kepada peserta didik. Hal ini berdampak pada 
kurangnya minat peserta didik dalam menerima pembelajaran yang mengakibatkan siswa sulit memahami konsep yang diterimanya.

Kelebihan menggunahkan model Kooperatif Tipe TGT dalam pembelajaran yaitu:

a) Dalam kelas kooperatif siswa memiliki kebebasan untuk berinteraksi dan menggunakan pendapatnya.

b) Rasa percaya diri siswa menjadi tinggi

c) Motivasi belajar siswa bertambah.

d) Pemahaman yang lebih mendalam terhadap materi pelajaran.

e) Meningkatkan kebaikan budi, kepekaan, toleransi, antara siswa dengan siswa dan antara siswa dengan guru.

Kekurangan menggunahkan model Kooperatif Tipe TGT dalam pembelajaran yaitu:

a) Sering terjadi dalam kegiatan pembelajaran tidak semua siswa ikut serta menyumbangkan pendapatnya.

b) Kekurangan waktu untuk proses pembelajaran. c) Kemungkinan terjadinya kegaduhan kalau guru tidak dapat mengelola kelas.

Berdasarkan data yang didapat peneliti hasil Wawancara peneliti di SMK PGRI 2 Palembang, Peserta didik menyatakan bahwa proses pembelajaran fisika berlangsung pasif, dimana peserta didik hanya sebagai pendengar informasi yang diberikan guru. Selain itu, selama melakukan proses pembelajaran, guru jarang menggunakan media sebagai pendukung dalam pembelajaran fisika. Konsep fisika yang sulit dimengerti membuat peserta didik beranggapan bahwa pelajaran fisika sulit sehingga menurunkan motivasi peserta didik yang berdampak pada kurangnya tingkat pemahaman konsep fisika. Penggunaan fasilitas sekolah seperti Laboratorium dan infokus juga kurang maksimal. Melalui wawancara dengan salah satu Guru Fisika SMK PGRI 2 Palembang yaitu lbu Susan Trissiana, S.Pd menyatakan bahwa keterbatasan waktu sebagai alasan utama kurang OptimaI Penggunaan fasilitas tersebut.Oleh sebab itu, melalui mata pelajaran fisika diharapkan siswa 
Agustina., Misdalina., Lefudin. - Pengaruh Model Pembelajaran ...

mampu mengembangkan kemampuan pemahaman dalam menyelesaikan masalah-masalah yang berkaitan dengan peristiwa alam sekitar.

\section{METODE}

Penelitian ini menggunakan penelitian yang digunakan oleh peneliti adalah metode True Experimental Design, Kategori Posstest-Only Control Design. Dalam Rancangan ini sering digunakan dalam Penelitian Eksperimen (Trianto, 2014:211).

Dalam melaksanakan pelaksanaan penelitian ini ada dua kelas, yaitu kelas eksperimen dan kelas kontrol. Kelas eksperimen merupakan kelas yang di beri perlakuan dengan menggunakan Model kooperatif tipe TGT sedangkan kelas kontrol merupahkan kelas yang tidak diberikan perlakuan menggunakan metode konvensional.

Penelitian ini dilaksanakan di SMK PGRI 2 Palembang Pada semester ganjil tahun ajaran 2019 yang berlokasi di Jl. Sapta Marga No.30 Bukit Sangkal,Kecamatan Kalidoni.Penelitian ini dilaksanahkan selama 1 bulan pada bulan Desember
Waktu yang diperlukan untuk penelitian ini dapat berubah sesuai kebutuhan.Populasi dalam penelitian ini adalah siswa kelas $\mathrm{X}$ yang terdiri dari 9 kelas dengan jumlah keseluruhan 299 siswa. Sampel dalam penelitian ini diambil menggunakan teknik cara random sampling. Hal ini dilakukan karena terdpat banyak sekali kelas caranya yaitu menguncang dalam botol seperti halnya arisan yang dimana yang keluar yang pertama di jadikan kelas eksprimen dan yang kedua dijadihkan kelas kontrol. Sampel dalam penelitian ada dua kelas yaitu kelas eksperimen $\mathrm{X}$ Teknik Otomotif 1 dengan jumlah 36 siswa diberi perlakuan menggunakan model Kooperatif Tipe TGT dengan materi elastisitas dan kelas kontrol X Teknik Otomotif 2 dengan jumlah 36 siswa ttidak menggunakan model Kooperatif Tipe TGT dengan materi elastisitas. Dari penelitian ini diperoleh data berupa hasil tes belajar siswa dengan diberi soal test berjumlah 20 butir soal pilihan ganda yang telah diuji validitas dan reliabilitasnya. 
Agustina., Misdalina., Lefudin. - Pengaruh Model Pembelajaran ...

Teknik pengumpulan data dalam semester ganjil tahun ajaran 2019 penelitian ini menggunahkan, tes, dan yang berlokasi di Jl. Sapta Marga dokumentasi. Analisis data dalam No.30 Bukit Sangkal,Kecamatan penelitian ini menggunakan uji Kalidoni. Dari pelaksanaan penelitian normalitas, homogenitas, dan uji dikelas eksprimen dan dikelas hipotesis.

\section{HASIL DAN PEMBAHASAN}

Penelitian ini dilaksanakan di SMK PGRI 2 Palembang Pada kontrol tersebut, pada kelas eksprimen yang menggunakan kooperatif tipe TGT siswanya aktif dalam kegiatan belajar mengajar. Bisa kita lihat dari gambar 1 .

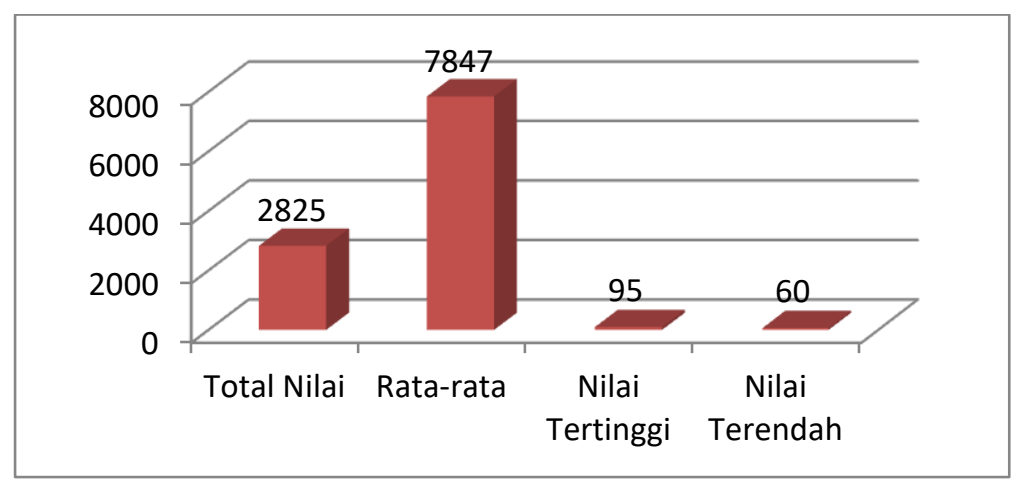

Gambar1. Hasil Nilai Eksprimen

Sedangkan pada kelas kontrol yang tidak menggunakan model Kooperatif Tipe TGT, dalam kegiatan belajar mengajar siswanya cenderung hanya mendengar, mengiat, terbukti dari gambar 2 .

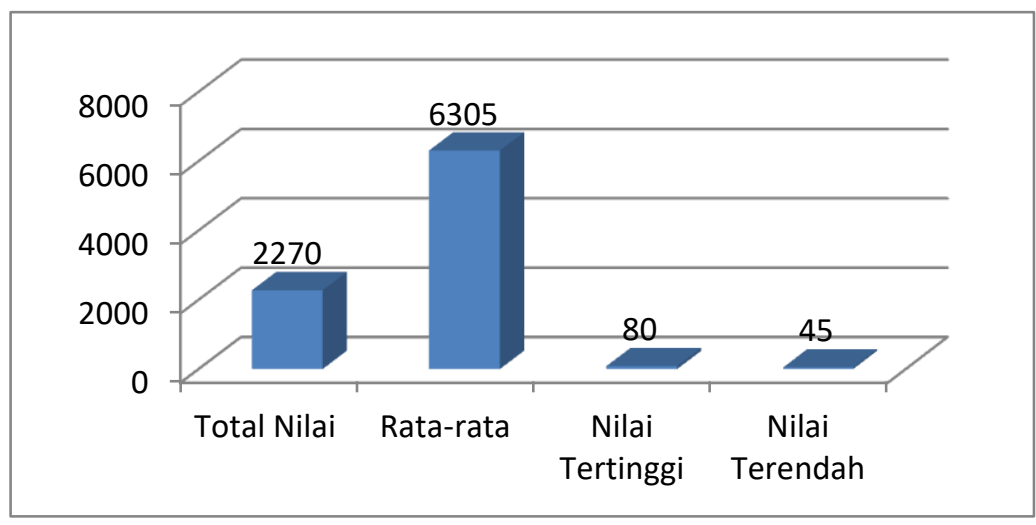

Gambar 2. Hasil Nilai Kontrol 
Agustina., Misdalina., Lefudin. - Pengaruh Model Pembelajaran ...

\begin{tabular}{|c|c|}
\hline $\begin{array}{l}\text { Terdapat pengaruh model } \\
\text { operatif Tipe Team Games }\end{array}$ & $\begin{array}{l}3,841 \text { dan } X_{\text {hitung }}^{2}=0,092 . \text { Diketahui } \\
\text { syarat homogen jika } X^{2}{ }_{\text {hituno }}<X_{\text {tahel }}^{2}\end{array}$ \\
\hline $\begin{array}{l}\text { Kooperatil Iipe Ieam Games } \\
\text { Tournament Terhadap Kemampuan }\end{array}$ & sampel berasal dari populasi \\
\hline $\begin{array}{l}\text { Pemahaman Konsep Peserta Didik } \\
\text { Pada Pembelajaran Fisika Kelas X }\end{array}$ & $\begin{array}{l}\text { homogen karena, } X^{2} \text { hitung }<X_{\text {tabel }}^{2} \\
(0,092<3,841) .\end{array}$ \\
\hline Di SMK PGRI 2 Palembang. & Dari hasil perhitungan diatas \\
\hline Berdasarkan hasil yang telah & tahap selanjutnya pengujian hipotesis \\
\hline $\begin{array}{lrr}\text { diperoleh } & \text { dari } & \text { penelitian, } \\
\text { menunjukkan } & \text { bahwa } & \text { model } \\
\text { pembelajaran Kooperatif Tipe } & \text { Team }\end{array}$ & $\begin{array}{l}\text { penelitian dengan menggunakan } \\
\text { rumus uji-t. Diperoleh } t_{\text {hitung yaitu }} \\
7,105 \text {, dibandingkan dengan } t_{\text {tabel }}\end{array}$ \\
\hline Games Tournament atau kelas & 1,667 untuk $d k=n 1+n 2-2=70$ \\
\hline diberihkan & dengan taraf signifikan $5 \%$ dengan \\
\hline perlakuan kelompok memiliki nilai & demikian $t_{\text {hitung }}>t_{\text {tabel. }}$ Berarti $\mathrm{Ha}$ \\
\hline yang lebih tinggi & diterima dan $\mathrm{H}_{\mathrm{o}}$ ditolak .Maka dapat \\
\hline dibandingkan dengan nilai rata-rata & disimpulkan \\
\hline kelas kontrol yang tidak diberi & pembelajaran \\
\hline perlakuan & Kooperatif Tipe \\
\hline pembelajaran konve & Tournament Terhadap Kemampuan \\
\hline Berdasarkan hasil perhitungan & Pemahaman Konsep Peserta Didik \\
\hline uji normalitas data pada kelas & Pada Pembelajaran Fisika Kelas X \\
\hline eksperimen diperoleh data normal & Di SMK PGRI 2 Palembang. \\
\hline karena nilai $\mathrm{Km}$ sebesar $-0,93$ harga & Model pembelajaran Kooperatif \\
\hline ini terletak antara $(-1)$ dan (1) dan & Tipe Team Games \\
\hline kelas kontrol juga diperoleh data & Trianto \\
\hline normal karena nilai $\mathrm{Km}$ sebesar $-0,01$ & pembelajaran \\
\hline harga ini terletak antara (-1) dan (1). & Tournament \\
\hline Kemudian & pembelajaran menambahkan bahwa \\
\hline homogenitas data $\mathrm{m}$ & pada model TGT siswa dibagi \\
\hline barlett, uji homogenitas data dalam & menjadi beberapa kelompok terdiri \\
\hline lic & dari $3-5$ orang \\
\hline$\%$ dengan & $\operatorname{gan}$ \\
\hline
\end{tabular}


Agustina., Misdalina., Lefudin. - Pengaruh Model Pembelajaran ...

tim lain untuk memperoleh tambahan poin untuk skor tim mereka. Pada model ini siswa saling berbagi ilmu terhadap kelompok lain yang dimana kelompok A sampai dengan E saling bergantian membagihkan informasi supaya materi yang diajarkan mudah diingat oleh siswa. Dalam strateginya belajar dan bermain supaya siswa tidak mengalami kejenuhan dalam belajar sehingga siswa tertarik dalam belajar.

Dalam proses kegiatan belajar pada penelitian ini, siswa dibagi menjadi 7 kelompok dimana masingmasing kelompok Terdiri dari 4 dan 5. Cara pembentukan kelompok dilakukan dengan mengurutkan siswa dari atas ke bawah dan dari bawah ke atas berdasarkan kemampuan akademiknya. setelah siswa duduk dengan kelompoknya masing-masing peneliti membagikan soal kepada siswa untuk di diskusikan oleh siswa, Fungsinya agar siswa lebih mendalami materi bersama teman kelompoknya serta dapat bekerja dengan baik dan optimal. Pada tahap ini siswa mulai menggorganisasikan ide-ide mereka untuk memahami masalah yang terdapat pada soal yang diberikan peneliti seperti tentang apa yang diketahui dan apa yang ditanyakan dengan bimbingan guru, dimana pada tahap ini kelompok siswa dituntun dalam menyelesaikan permasalahan yang dihadapi.

Selanjutnya setelah siswa memahami masalah, siswa memikirkan kembali, mendalami dan menggali informasi yang sudah didapat dalam kegiatan diskusi sesama kelompoknya. Sehingga pada tahap inilah siswa dapat mengisi jawaban soal-soal yang sudah di diskusikan sesama kelompoknya dan melaksanakan penyelesaiannya dengan bimbingan peneliti. Dari tahapan -tahapan inilah siswa memiliki kebebasan untuk berinteraksi menggunakan pendapatnya, rasa percaya diri siswa menjadi tinggi, motivasi belajar siswa bertambah, serta meningkatnya kebaikan budi, kepekaan, toleransi antara siswa dengan siswa dan antara siswa dengan guru. Setelah siswa selesai mengerjakan soal yang diberikan peneliti, peneliti menyimpulkan jawaban dari masingmasing kelompok siswa untuk di 
Agustina., Misdalina., Lefudin. - Pengaruh Model Pembelajaran ...

diskusikan bersama, Turnamen selesai, peneliti mengumumkan tiga kelompok yang mempunyai poin yang tertinggi diantara kelompok yang lain yang akan mendapatkan piagam penghargaan.

Pada penelitian yang dilakukan oleh Agus (2017) dengan judul penelitian "TGT Dalam Pembelajaran Fisika di MAN 2 Jember (pokok bahasan Analisis Gerak Lurus Dua Di Mensi Tahun Ajaran 2017/2018”) Dimana pada penelitian ini, instrument yang digunakan adalah tes berbentuk pilihan ganda. Sehingga berdasarkan hasil analisis data yang telah dilakukan, diperoleh bahwa hasil nilai- kelas eksperimen lebih besar dari pada kelas kontrol. Selain itu pada pengujian hipotesis juga nilai $\mathrm{t}$ hitung lebih besar dari pada nilai $\mathrm{t}$ tabel. sehingga dapat disimpulkan terdapat perbedaan hasil nilai yang menggunakan model TGT terbukti dari hasil nilai siswa.

Sedangkan untuk pembelajaran yang dilakukan pada kelas kontrol adalah pembelajaran konvensional yang berpusat pada guru. Peneliti memberikan materi serta contoh soal, menyuruh siswa menjawab contoh soal lalu memberikan latihan kepada siswa. Peneliti juga memberikan kesempatan kepada siswa untuk bertanya mengenai materi yang belum dimengerti. Pada proses pembelajaran ini pada awalnya membuat siswa menjadi lebih tenang .Siswa duduk dan memperhatikan guru menerangkan materi pelajaran. Hal semacam ini menjadikan peneliti sulit mengetahui kemampuan peserta didik, karena peserta didik yang belum paham tidak mau bertanya. Hubungan timbal balik yang terjadi hanya satu arah, yaitu dari peneliti ke siswa. Sementara hubungan timbal balik dari siswa ke peneliti atau dari siswa ke siswa hampir tidak ada.

Peranan peneliti yang sangat dominan ini mengakibatkan dalam proses belajar mengajar peneliti mengakibatkan kurang adanya respon yang baik, serta secara tidak langsung melemahkan cara berpikir siswa, juga dapat mengakibatkan kecanggungan siswa untuk mengeksplor atau mengemukakan ide, gagasan, atau pemikiran siswa dalam proses pembelajaran tersebut. Oleh karena itu, kemampuan 
Agustina., Misdalina., Lefudin. - Pengaruh Model Pembelajaran ...

pemahamn konsep peserta didik di kelas kontrol lebih rendah dari pada kelas eksperimen.

Terdapat perbedaan hasil belajar baik itu tinggi, sedang, rendah, pada penelitian ini. Karna yang telah dilakukan oleh peneliti pada pertemuan pertama siswa mulai memahami materi, pertemuan kedua siswa mulai menunjukan hasil pembelajaran yang hampir mencapai penguasaan materi, dan siswa mulai menguasai materi pembelajaran yang dimana ditunjukan pada pemberian soal kepada siswa nilai yang didapatkan,lalu peneliti memberikan soal tes kepada siswa pada akhir pembelajaran, menunjukan secara keseluruhan bahwa terdapat perbedaan hasil belajar yaitu dengan menggunahkan model Team Games Tournament yang diberikan perlakuan, dan metode ceramah yang tidak diberikan perlakuan.

Hal ini diperkuat oleh hasil penelitian Tara Ulfa (2020) yaitu dimana hasil tes model pembelajaran Team Games Tournamentpeserta didik nilai rata-rata menjadi 76,8 Team Games Tournament. Hasil tersebut menunjukkan bahwa menggunakan model pembelajaran berkategori baik dan harus dipertahankan.

\section{KESIMPULAN DAN SARAN}

\section{Kesimpulan}

Berdasarkan data hasil pengujian hipotesis, maka dapat dikemukakan beberapa kesimpulan yaitu terdapat Pengaruh Model Pembelajaran Kooperatif Tipe Team Games Tournament Terhadap Kemampuan Pemahaman Konsep Peserta Didik Pada Pembelajaran Fisika Kelas X Di SMK PGRI 2 Palembang. Selain itu, terdapat Perbedaan hasil belajar baik itu tinggi, sedang, rendah, rendah, pada penelitian ini.

\section{DAFTAR PUSTAKA}

Gunawan, G., Harjono, A., \& Imran, I. (2016). Pengaruh Multimedia Interaktif dan Gaya Belajar Terhadap Penguasaan Konsep Kalor Siswa. Jurnal Pendidikan Fisika Indonesia, 12(2), 118-125.

Sufairoh. (2016). Pendekatan Saintifik \& Model Pembelajaran K-13. Jurnal Pendidikan Profesional, 116.

Suprihatiningrum, J. (2016). Straregi Pembelajaran. Yogjakarta : ArRuzz, Media. 
Agustina., Misdalina., Lefudin. - Pengaruh Model Pembelajaran ...

Sari, P.I. (2016). Penggunaan Model

Team Games Tournament

Pada Penguasaan Konsep

Fisika. Jurnal Pendidikan

Fisika dan Teknologi, 176.

Trianto. (2014). Mendesain Model Pembelajaran inovatif, Progresif, dan Kontekstual. Jakarta: Pranamedia Grup.

Ulfia, T., \& Irwandani, I. (2019). Model Pembelajaran Kooperative Tipe Teams Games Tournament (TGT):
Pengaruhnya Terhadap

Pemahaman Konsep.

Indonesian Journal of Science and Mathematics Education, 2(1), 140-149.

Prihatiningtyas, S., Prastowo, T., \& Jatmiko, B. (2013). Imlementasi simulasi PhET dan KIT sederhana untuk mengajarkan keterampilan psikomotor siswa pada pokok bahasan alat optik. Jurnal Pendidikan IPA Indonesia, 2(1). 